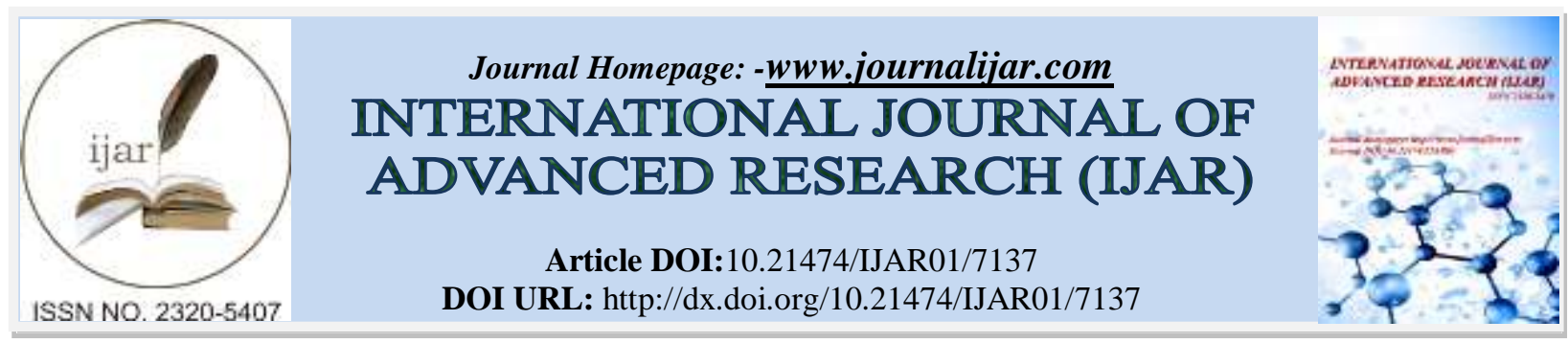

RESEARCH ARTICLE

\title{
NANOEMULSION OF GINGER RHIZOME (ZINGIBER OFFICINALE) EXTRACT AS A PRESERVATIVE FOR SWEET LEMON SQUASH: AN ALTERNATIVE TO REDUCE THE USE OF BENZOIC ACID.
}

\author{
Kailash Barman ${ }^{1}$, Devasish Chowdhury ${ }^{2}$ and Pranjal K. Baruah ${ }^{1}$. \\ 1. Department of Applied Sciences, GUIST, Gauhati University -781014, Assam, india. \\ 2. Institute of Advanced Study in Science and Technology, Guwahati-781035, Assam, india.
}

Manuscript Info
Manuscript History
Received: 19 March 2018
Final Accepted: 21 April 2018
$\begin{aligned} & \text { Keywords:- } \\ & \text { Ginger, Nanoemulsion, Sweet lemon } \\ & \text { squash, Antimicrobial, Natural } \\ & \text { preservative, Benzoic acid. }\end{aligned}$

\begin{abstract}
Commonly used chemical preservatives used in many processed food products have an adverse impact on consumer health due to regular consumption over a long period of time. We have developed a nanoemulsion (NE) of ginger extract as natural food preservative (alternative to chemical preservative commonly used) in a sweet lemon squash. NE was prepared by using ginger rhizome extract, Tween 80 and water has an effective diameter of $91.67 \mathrm{~nm}$. After the application of NE in sweet lemon squash, we have performed physico-chemical analysis, in-vitro microbial analysis, and storage studies of shelf-life determination. The efficacy of the NE was compared with samples preserved with chemical preservative. The composition of ginger extract was analyzed, and their impact on physical and chemical properties of sweet lemon squash was also evaluated. Antimicrobial activity of NE was evaluated against two microbial species, Escherichia coli (Gram negative) and Staphylococcus aureus (Gram positive) and it showed excellent antimicrobial property.
\end{abstract}

Copy Right, IJAR, 2018,. All rights reserved.

\section{Introduction:-}

Demand for fresh/minimally processed foods like fruits and vegetables have increased rapidly due to enhanced consumer awareness of healthy food habit. There are numerous varieties of products processed from fresh produce, most of which are very popular as nutritious food choices, and are considered to be perishable in nature. Clearly, fresh fruits and food products and beverages need to be preserved for achieving relatively enhanced shelf-life facilitating storage and/ or transportation(Nowak et al., 2016 and Santos et al., 2015).On an average, eighteen percent (18\%) of India's freshly harvested fruits and vegetables valued at Rs. 133 billion are wasted due to lack of proper preservation system (Sagheer et al., 2009). Such wastes may also create an imbalance in market demandsupply ratio, and hence overall business and trade of fresh fruits to consumers throughout the year, effective preservation strategies need to be applied. Conversion of fruits into packaged fruit product is one of the effective preservation techniques for prevention of contamination and/or spoilage of the fruit-derived products, including juice. Fruit preservation, if effectively implemented, prevents contamination from the foodborne pathogen(s) and minimizes the risk of incidence of foodborne infection/outbreak. However, traditional processing/preservation parameters applied in fruit manufacturing may affect the nutritional quality of fruits (Rawson, 2011). Chemical preservatives such as weak organic acid like acetic acid, lactic acid, benzoic acid and sorbic acid are effective in 
inhibiting microbial growth (Brul, 1999). However, some of the chemical preservatives may cause a negative impact on consumer's health. The United States Food and Drug Administration (USFDA) enacted Food Safety Modernization Act (FSMA) in 2011 and updated limits for use of a chemical preservative in foods and beverages. In this context, scientists, research scholars, and fruit processors are evaluating 'natural' alternative(s) to chemical preservative(s). There are many well-established thermal and non-thermal preservation techniques that are frequently used, e.g. pasteurization, boiling, exposure to UV radiation, high pressure processing, chilled storage (refrigeration), and use of polyethylene terephthalate (PET) packaging, which have significantly improved shelf life of processed fruits (Chirife and Favetto, 1992). Previous researchers have yielded promising results in the application of exotic fruit component(s) as a natural preservative(s) in fruit-based products (Nowak et al., 2016). People have used plants extract as a preservative with two or more plants (Amrutha et al., 2017). However, use of many extracts would make the process expensive (Mishra et al., 2015). Moreover, the use of rare plants like Aloe vera will make the process uneconomical.

In this study, NE of ginger rhizome extract(s) (Zingiberofficinale) was used as a natural preservative. Ginger is available in northeast India and farmers of northeast India produces 70\% India's high-quality ginger in every year (Rahman et al., 2010). It is easy to purchase ginger with cheap market price and, due to the availability and cheap price it is more economic. After the application of NE in sweet lemon squash, the physicochemical analysis was carried out. The in-vitro microbial analysis show NE possesses excellent anti-bacterial activity. The storage studies indicated that application of NE prevents the deterioration of squash up to sixty days of storage at room temperature and its efficacy is comparable to the common chemical preservative used.

\section{Materials and methods:-}

Extraction of fruit juice from sweet lemon:-

Fresh sweet lemons (Citrus limetta) were purchased from a local market in Kokrajhar, Assam, India. The fruits were washed carefully under flowing tap water, peeled, cut into pieces, deseeded and then juiced with a mechanical extractor and then kept in a sterile glass container at $4^{\circ} \mathrm{C}$ for further analysis.

\section{Extraction of bioactive compounds from ginger:-}

The powder of the locally available raw ginger rhizome (Zingiber officinale) was prepared by oven drying method at $65^{\circ} \mathrm{C}$ for $8 \mathrm{~h}$ (Jayashree et al., 2014) and next step followed by Soxhlet extraction of the powder using ethanol as solvent (Hasan et al., 2012). Dry powdered ginger (45 g) was placed inside a thimble connected to the Soxhlet extraction unit. Ethanol was added to the round-bottomed flask. The solvent was refluxed for $12 \mathrm{~h}$ and the total amount of solvent was maintained $450 \mathrm{~mL}$ refluxing over the sample continuously. The solvent was allowed to cool to the room temperature and removed under reduced pressure using rotary evaporator (Buchi/Switzerland). To obtain a complete dry extract, the contents were removed and placed in glass plates and kept for drying at $40^{\circ} \mathrm{C}$ inside an oven for $24 \mathrm{~h}$. The extracts were stored under refrigerator $\left(4^{\circ} \mathrm{C}\right)$ until further studies are done.

GC-MS (Gas Chromatography-Mass Spectrometry) analysis of ginger rhizome extract:-

The GC-MS analysis of the ethanol extract of ginger rhizome (phytochemical investigation) was performed on a GC-MS spectrometer (Shimadzu/Japan) consisting of a GC-2010 gas chromatograph and a GC-MS QP2010 plus GC mass spectrometer. The experiment was carried out on Rtx $-5 \mathrm{MS}$ quartz capillary column $(60 \mathrm{~m} \times 0.25 \mathrm{~mm})$ with cross bond R $5 \%$ diphenyl / $95 \%$ dimethyl polysiloxane stationary phase. In the temperature program, the temperature was raised to $80^{\circ} \mathrm{C}$ for $1 \mathrm{~min}$. After that, the temperature was increased to $180^{\circ} \mathrm{C}$ at a rate of $10^{\circ} \mathrm{C} / \mathrm{min}$ and kept for 4 minutes, then with $15^{\circ} \mathrm{C} / \mathrm{min}$. to $300^{\circ} \mathrm{C}$ and kept for 17 minutes. The injection volume of sample was $0.3 \mu \mathrm{L}$ with a split ratio $1: 20$, run time 56 minutes and pressure at the column inlet $163.3 \mathrm{kPa}$ with helium carrier gas at $1.21 \mathrm{ml} / \mathrm{min}$ flow rate. Identification of compounds (Table 1) was done by comparison of mass spectra with those in the Wiley and NIST Libraries (Bhargava et al., 2012). 


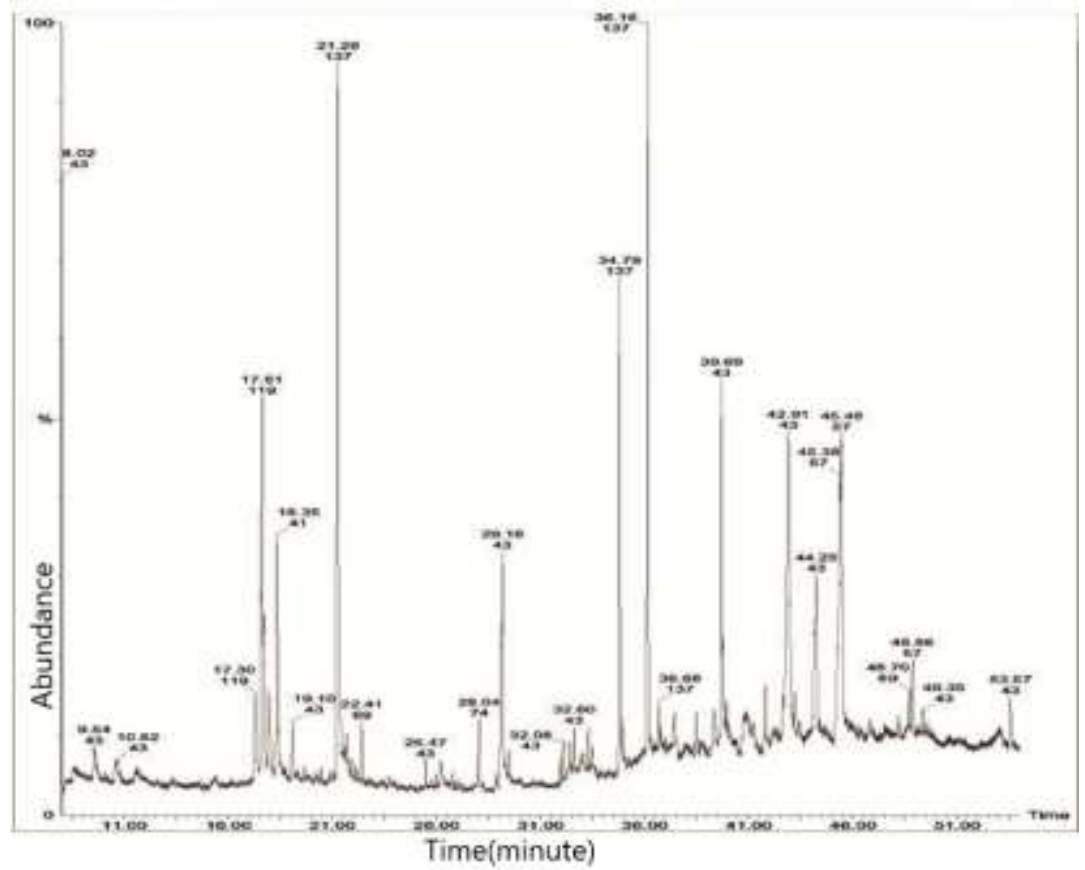

Fig. 1:-GC-MS analysis of nanoemulsion (NE) for active compounds.

Table 1:-GC-MS analysis of NE for active compounds

\begin{tabular}{|l|l|l|l|l|l|}
\hline Sl. No. & $\begin{array}{l}\text { Retention time } \\
(\text { RT) (minute) }\end{array}$ & Area\% & Name of compound & $\begin{array}{l}\text { Chemical } \\
\text { formula }\end{array}$ & $\begin{array}{l}\text { Molecular weight } \\
(\mathrm{MW})\end{array}$ \\
\hline 1. & 17.30 & 0.85 & Rosifaliol & $\mathrm{C}_{15} \mathrm{H}_{24} \mathrm{O}$ & 220 \\
\hline 2. & 17.61 & 1.54 & $\beta$-bisabolol & $\mathrm{C}_{15} \mathrm{H}_{26} \mathrm{O}$ & 222 \\
\hline 3. & 18.35 & 0.70 & 2-Norbornanone & $\mathrm{C}_{15} \mathrm{H}_{24} \mathrm{O}$ & 220 \\
\hline 4. & 21.26 & 9.21 & Dlepi- $\alpha$ edrenepoxide & $\mathrm{C}_{15} \mathrm{H}_{24} \mathrm{O}$ & 220 \\
\hline 5. & 22.41 & 0.33 & Methyl Icosanoate & $\mathrm{C}_{21} \mathrm{H}_{42} \mathrm{O}_{2}$ & 326 \\
\hline 6. & 28.04 & 7.45 & 6-hydroxy-6-shogalol & $\mathrm{C}_{8} \mathrm{H}_{16} \mathrm{O}_{2}$ & 236 \\
\hline 7. & 29.16 & 0.21 & 6-dehydro-8-gingerol & $\mathrm{C}_{19} \mathrm{H}_{30} \mathrm{O}_{4}$ & 322.445 \\
\hline 8. & 34.79 & 4.46 & Gingerol & $\mathrm{C}_{17} \mathrm{H}_{26} \mathrm{O}_{4}$ & 294.38 \\
\hline 9. & 36.16 & 14.12 & Zingiberene & $\mathrm{C}_{15} \mathrm{H}_{24}$ & 204.357 \\
\hline 10. & 39.69 & 6.13 & Amentol & $\mathrm{C}_{6} \mathrm{H}_{14} \mathrm{O}_{6}$ & 182.172 \\
\hline 11. & 41.80 & 1.13 & $\alpha$-Selinene & $\mathrm{C}_{15} \mathrm{H}_{24}$ & 204.357 \\
\hline 12. & 44.25 & 0.13 & Zingerone & $\mathrm{C}_{11} \mathrm{H}_{14} \mathrm{O}_{3}$ & 194.2271 \\
\hline 13. & 45.46 & 0.11 & $\beta$-Eudesmol & $\mathrm{C}_{15} \mathrm{H}_{26} \mathrm{O}$ & 222.372 \\
\hline
\end{tabular}

Within the retention between 17 minutes to 46 minutes compounds were found which are shown in Table 1 .

\section{Preparation of NE:-}

The ethanolic extract of ginger rhizome, a non-ionic surfactant (Tween 80) and water was mixed in a specific proportion to make the NE. The ginger extract and surfactant were mixed at ratios of 1:6, 1:5, 1:4, 1:3, 1:2 and 1: $1(\mathrm{v} / \mathrm{v})$ and final volume were made up to $50 \mathrm{~mL}$ using water (Ghosh et al., 2013). First, the coarse emulsion was initially mixed with a magnetic stirrer at $140 \mathrm{rpm}$ at room temperature. This solution was again mixed using the high energy method, an ultrasonic horn processor. The arrangement maintains a frequency of $20 \mathrm{kHz}$ with a maximum output of $750 \mathrm{~W}$ that could be delivered with the flexible control of amplitude $40 \%$ (Sonics \& Materials, Inc., Newtown, USA). Sonication was done at ambient temperature for $10 \mathrm{~min}$, where, each cycle consisted of 30 second pulses on and 1 second pulses off in an ultrasonic Homogenizer (Sonics-Vibracell, USA) with a maximum power output of $750 \mathrm{~W}$. The probe diameter was $13 \mathrm{~mm}$ for homogenization; heat generated during the process was nullified by indirect contact with ice in beaker. The formulated NE was then characterized. 


\section{Determination of particle size of NE:-}

The particle size of the formulated NE was determined by using a particle size analyzer Malvern Zetasizer Nanoseries, Nano-ZS90 (Amrutha et al., 2017).

\section{Microbial analysis:-}

Determination of antimicrobial activity of NE by disk diffusion method:-

Determination of antimicrobial activity was done according to the methods suggested by the National Community for Clinical Laboratory Standards (CLSI- Performance Standards for Antimicrobial Susceptibility Testing, 2013). The following bacterial strains were used in the antimicrobial assays: gram-positive: Staphylococcus aureus (ATCC 25923) and gram-negative: Escherichia coli (ATCC 25922).

All strains were collected from the CSIR- National Chemical Laboratory (Pune, India). Briefly, a suspension of the tested microorganisms $(100 \mu \mathrm{L}$ of $106-108 \mathrm{CFU} / \mathrm{mL}$ ) was uniformly swabbed on agar plates (Mueller Hinton Agar) using sterile cotton swabs. Sterile blank discs (6 mm in diameter) were individually impregnated with $15 \mu 1,10 \mu 1$ and $5 \mu \mathrm{l}$ of emulsion and positioned onto the inoculated agar plates. Plates were incubated at $37^{\circ} \mathrm{C}$ for $24 \mathrm{~h}$.

Antimicrobial activity was determined by measuring the diameter of the resulting zone of inhibition (ZOI) against the tested microorganisms in millimeters. $100 \%$ dimethyl sulfoxide (DMSO) $(15 \mu \mathrm{L}$ per blank disc) was used as negative control. This assay was performed in triplicate (Table 2).

Determination of minimum inhibitory concentration (MIC) of NE:-

MIC of NE was determined by the method described by Sarker et al. (2007), after minor modifications. A sterile 96 well plate was labeled. A volume of $100 \mu \mathrm{L}$ of test material with $10 \%(\mathrm{v} / \mathrm{v})$ DMSO was pipetted into the first row of the plate. To all other wells, $50 \mu \mathrm{L}$ of nutrient broth was added. Serial dilutions were done using a multichannel pipette. The tips were changed after use such that each well had $50 \mu \mathrm{L}$ of the test material in serially descending concentrations. To each well $10 \mu \mathrm{L}$ of the resazurin indicator solution was mixed. Lastly, $10 \mu \mathrm{L}$ of bacterial suspension $\left(5 \times 10^{6} \mathrm{CFU} / \mathrm{mL}\right)$ was mixed with each well to achieve a concentration of $5 \times 10^{5} \mathrm{CFU} / \mathrm{mL}$. Each plate was wrapped loosely with cling film to make sure that bacteria did not become dried out. Each plate had a set of controls: a column with a broad-spectrum antibiotic as a positive control (Ciprofloxacin in serial dilution), a column with all solutions with the exception of the test compound, and a column with all solutions with the exception of the bacterial solution adding $10 \mu \mathrm{L}$ of nutrient broth instead. The plates were prepared in triplicate and placed in an incubator set at $37^{\circ} \mathrm{C}$ for $24 \mathrm{~h}$. The change of color was then assessed visually. Any color changes from purple to pink or colorless were recorded as positive. The lowest concentration at which change of color occurred was taken as the MIC value.

\section{Determination of microbial load of squash (Total Plate count):-}

For microbial analysis $1.0 \mathrm{~mL}$ of squash was diluted with $10 \mathrm{~mL}$ of saline solution and filtered through sterile Whatman No. 1 filter paper to remove solid particles. $1.0 \mathrm{~mL}$ of filtrate was used for inoculation. Samples were serially diluted in saline and incubated at $37^{\circ} \mathrm{C}$ for $24 \mathrm{~h}$. Plate count agar was used for this experiment (Harrigan and McCance, 1966).

\section{Formulation of squash:-}

The lemon squash was prepared as per standard procedure, juice content $25 \%$, acidity $1 \%$, TSS (Total soluble solid) $46.7 \%$ (Syed et al., 2012). The procedure of squash preparation is given in Figure 2. Two batches of Sweet lemon squash were prepared (batch coded as T1 and T2). First, the T1 batch was prepared with benzoic acid (600 $\mathrm{mg} / \mathrm{L})$ as control and second $\mathrm{T} 2$ batch formulated with a mixture of benzoic acid $(200 \mathrm{mg} / \mathrm{L})$ and NE of ginger rhizome (Zingiberofficinale) extract $(800 \mathrm{mg} / \mathrm{L})$ to reduce the use of benzoic acid. The final brisk value of the squash was maintained at $45^{\circ}$ Brix. Finally, the squash was kept in a sterile glass bottle with the airtight condition at room temperature for further studies. 


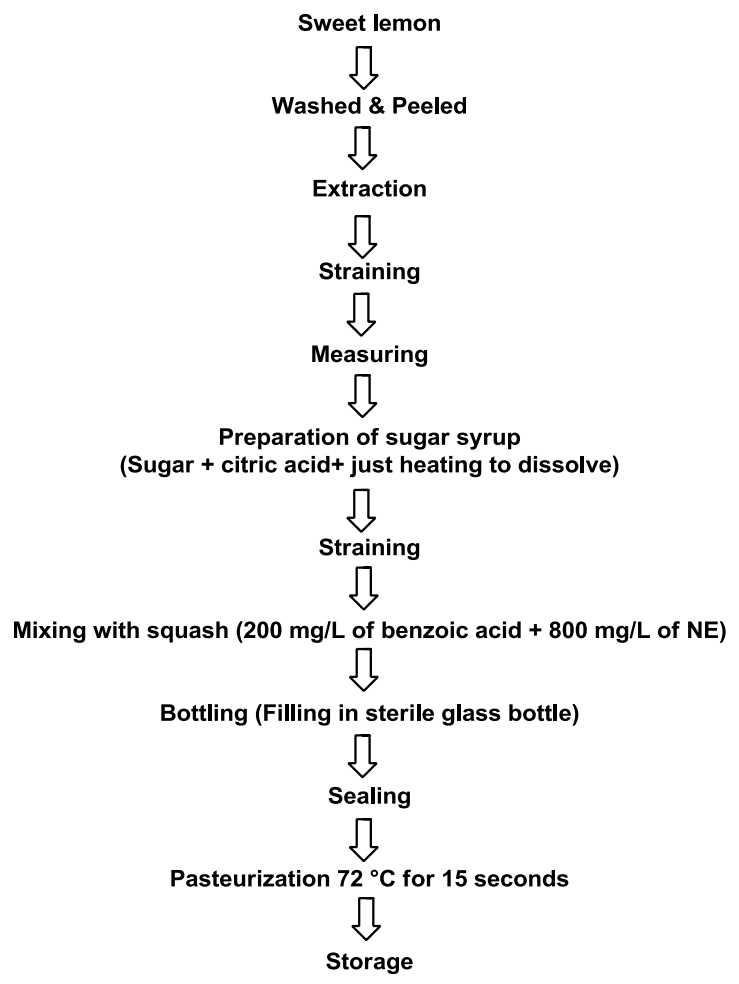

Fig. 2:-Flow chart for the preparation of sweet orange squash with NE

Measurement of color:-

A colorimeter (D25LT Hunter Lab, Reston, VA, USA) was used for the analysis of the color (Billmeyer, 1983). The instrument was calibrated with black and white tiles before use. A glass cell with a white ceramic lid on the top was used for holding the samples $(20 \mathrm{~mL})$. The color of the samples was measured in reflectance mode, using the CIELAB* coordinate system (light source: D65; 10" observer). The color difference between the enriched sample and the control was also calculated as:

$\Delta \mathrm{E}^{*}=\sqrt{\Delta L *^{2}+\Delta \mathrm{a} *^{2}+\Delta \mathrm{b} *^{2}}$

Where:

$\Delta \mathrm{L} *=(\mathrm{L} *$ sample $-\mathrm{L} *$ control $)$

$\Delta \mathrm{a}^{*}=\left(\mathrm{a}^{*}\right.$ sample $-\mathrm{a}^{*}$ control $)$

$\Delta \mathrm{b}^{*}=\left(\mathrm{b}^{*}\right.$ sample $-\mathrm{b}^{*}$ control $)$

\section{Determination of chemical characteristics of sweet lemon squash:-}

The chemical characteristics of sweet lemon squash such as moisture content, protein, fat, carbohydrate, ash, and fiber were determined as per standard procedure (AOAC, 2012).

\section{Sensory Analysis:-}

Sensory analysis (Tyagi, 2014) was conducted for choosing samples (T1, T2) during storage. Sensory evaluation panel made by female members and age ranges from 35 to 60 years. All these members have a lot of knowledge and research work related to the sensory evaluation of food materials. The sensory evaluation was done in artificial light and the temperature of samples approximated the normal temperature.

\section{Statistical analysis:-}

All data are shown as the mean \pm standard deviation (SD) of measurements. Three replicates were used for all tested parameters. Statistical comparisons were completed using student's $t$-test with SPSS 16 software. P-values lower than 0.05 were considered as significant. 


\section{Result and discussion:-}

In this work, $\mathrm{NE}$ of the ginger extract was applied as a natural preservative in the preparation and preservation of sweet lemon squash to prolong the shelf life. The NE of ginger rhizome extracts possesses both antifungal and antimicrobial activities (Rahmani, 2014). The application of synthetic and semi-synthetic antimicrobial compound can be reduced along with food borne pathogens using NE of ginger extract (Islam et al., 2014).

\section{Extraction and GC-MS analysis of ethanolic extract of Zingiber officinate (Ginger roots):-}

Figure 1 shows GC-MS of ethanol extract from ginger rhizomes obtained from a locally available market of Assam, India. Earlier, it was reported that the presence of microbial compound of ginger rhizomes are gingerol, zingiberene, $\beta$-bisabolene, shogaol, $\beta$-sesquiphellandrene, etc. (Bhargava et al., 2012). However, the ginger rhizomes of Assam, North- East India have little different chemical composition compared to earlier study.

\section{Preparation and particle size determination of the NE:-}

Droplet sizes of the NE over 15 min of ultrasonic emulsification were measured (Figure 3). NE with 1:1 (v/v) ratio of oil ( $8 \%$ of the total emulsion volume) and surfactant ( $8 \%$ of the total emulsion volume) respectively exhibited highest droplet diameter $(91.67 \mathrm{~nm})$. Tween 80 was used as a surfactant as it has a high hydrophilic-lipophilic balance (HLB-15) and favorable for the oil-in-water emulsion. Also, being a small molecule surfactant Tween 80 is comparatively effective when it is in the form of minimizing droplet diameter than polymers due to their rapid adsorption onto the droplet (Qian and McClements 2011).

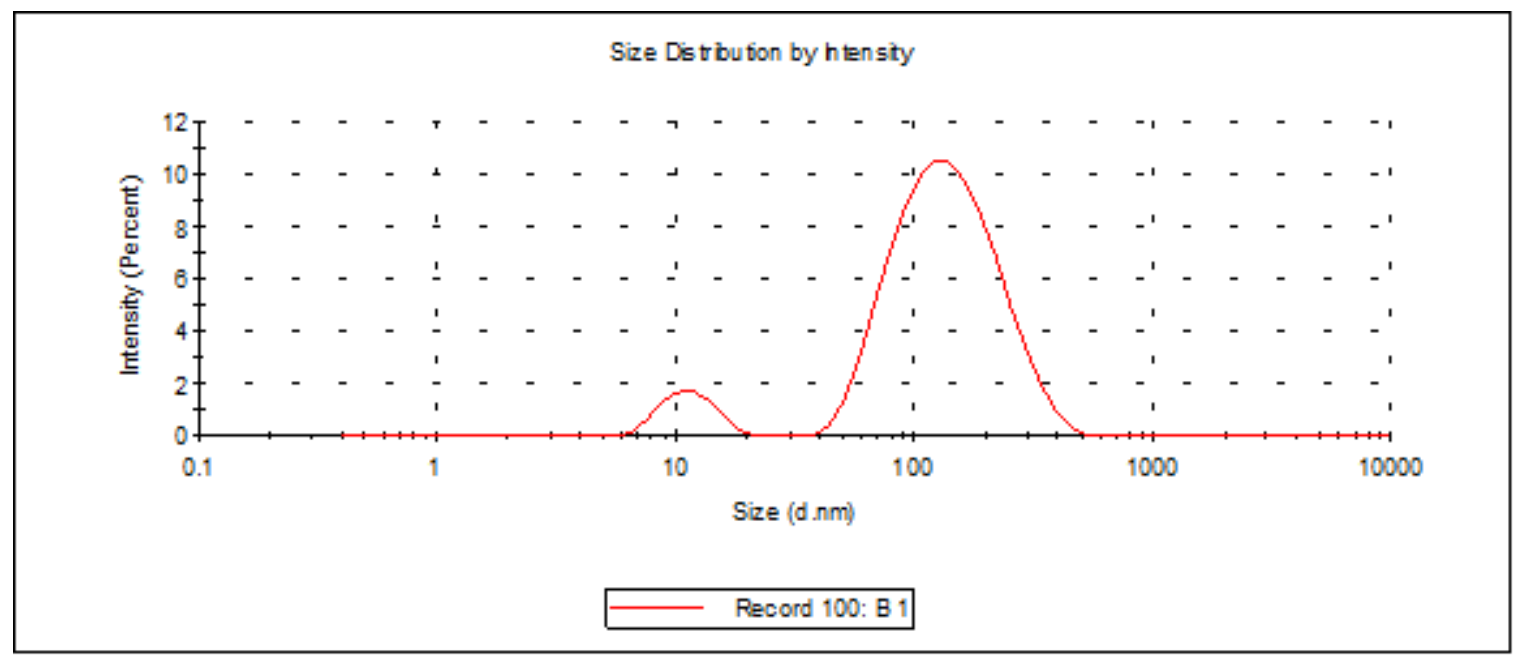

Fig. 3:-Particle size determination of the NE

\section{Microbial analysis:-}

Antimicrobial activity studies of NE by disk diffusion method:-

Antimicrobial activity of NE was studied using disk diffusion method. When the NE was assayed against the bacteria (Escherichia coli and Staphylococcus aureus) by disk diffusion method, the zones of inhibition (Figure 4) obtained and tabulated in Table 2. These results indicate that the NE retained its anti-bacterial activity due its nanosized droplets and anti-microbial compound (s) tabulated in Table 1. 

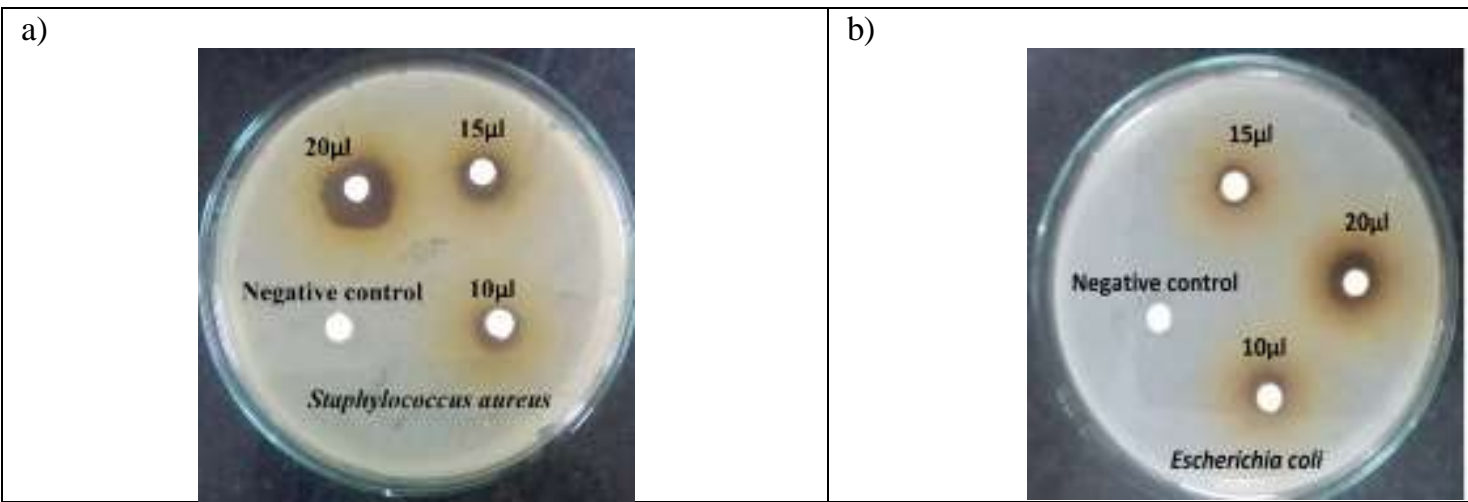

Fig. 4:-Antimicrobial activity of NE $(20 \mu 1,15 \mu 1,10 \mu 1 \&$ negative control) by disc diffusion method against a) $S$. aureus and b) E. coli

Evaluation of minimum inhibitory concentration (MIC) values:-

The antimicrobial activity of NE was initially evaluated by a broth micro dilution method using two strains of pathogenic bacteria (Escherichia coli and Staphylococcus aureus). This extract exhibited strong antimicrobial activity. The results obtained in the broth dilution assay regarding the MIC range of the tested microbes are shown in (Table 2).

Table 2:-Minimum inhibitory concentration (MIC) of NE by serial broth dilution method and Disc diffusion test [zone of inhibition] for NE

\begin{tabular}{|l|l|l|l|l|}
\hline Test microorganism & MIC range $(\mathrm{mg} / \mathrm{ml})$ & \multicolumn{3}{|l|}{$\begin{array}{l}\text { Zone of inhibition in diameter }(\mathrm{mm}) \text { for different } \\
\text { concentration of NE }\end{array}$} \\
\cline { 3 - 5 } & & $10 \mu 1$ & $15 \mu 1$ & $20 \mu 1$ \\
\hline E. Coli & $2.0 \pm 0.04$ & $8.12 \pm 0.32$ & $9.5 \pm 0.14$ & $12.9 \pm 0.12$ \\
\hline S. Aureus & $1.70 \pm 0.02$ & $9.2 \pm 0.13$ & $10.3 \pm 0.11$ & $14.5 \pm 0.17$ \\
\hline
\end{tabular}

Each value is the mean $\pm \mathrm{SD}(\mathrm{n}=3)(\mathrm{p}<0.05)$.

Total plate count of formulated fruit squash:-

The microbial spoilage of the squash was studied by total plate count method after a ten day of interval up to 60 days of storage. The microbial count for bacteria was zero after 60 days of storage. This clearly indicates that both formulations of (T1 and T2) of sweet lemon squash under investigation were free from any microbial spoilage up to two months of storage. Ginger shows antimicrobial and other biological activities due to the presence of gingerol and paradol, shogaols and zingerone in the NE (Giriraju and Yunus, 2013). The NE particles are thermodynamically driven to fuse with the lipid-containing organism. This fusion is enhanced by the electrostatic attraction between the cationic charge of the emulsion and the anionic charge on the pathogen. When enough nanoparticles fuse with the pathogens, they release part of energy trapped within the emulsion. The energy released and the active ingredients disrupt the pathogen lipid membrane which results in cell lysis and death (Teixeira et al., 2007). For this reason, the NE showed similar antimicrobial activity when compared with chemical preservative (e.g. benzoic acid) in fruit squash.

\section{Formulation of squash:-}

The majority of preservatives used today are artificial rather than natural (Anand and Sati 2013). Some of them are toxic and several others have potentially life-threatening side effects such as hypersensitivity, allergy, asthma, hyperactivity, neurological damage, and cancer. Several natural preservatives obtained from plants, animals, microbes, and minerals contain antioxidant, antimicrobial and anti-enzymatic properties. Extracts of basil, clove, neem, ginger rhizome and rosemary are promising alternatives to their artificial counterparts. We have utilized ginger rhizome extract for the preparation of NE which was added in the fruit squash in order to reduce the dose of artificial preservative for preservation. Ginger has long been used as naturopathy due to their potential antimicrobial activity against different microbial pathogens (Gull et al., 2012). Benzoic acid is anti-fungal and the active compound of ginger have anti-bacterial activity (Amborabé et al., 2002). So, a combination of both benzoic acid and 
NE was applied in sweet lime squash to prolong shelf life. Further, a reduced dose of benzoic acid is used which is healthier for the consumer.

\section{Physiochemical characteristics of sweet lemon squash:-}

Physiochemical characteristics of formulating sweet lemon squash with NE of ginger rhizome extract as a natural preservative were studied. Sweet lemon squash was analyzed for different chemical properties such as moisture, $\mathrm{pH}$, acidity, TSS, Vitamin C. The obtained data on chemical properties of sweet lemon squash is presented in Table 3.

Table 3:-Physiochemical characteristics of sweet orange squash

\begin{tabular}{|l|l|}
\hline Parameters & Value \\
\hline $\mathrm{pH}$ & $3.7 \pm 0.01$ \\
\hline TSS (0Brix) & $10 \pm 0.02$ \\
\hline Acidity (\%) & $0.41 \pm 0.01$ \\
\hline Moisture (\%) & $88.4 \pm 0.03$ \\
\hline Protein (\%) & $0.6 \pm 0.02$ \\
\hline Fat (\%) & $0.05 \pm 0.001$ \\
\hline Total Carbohydrate (\%) & $10.5 \pm 0.01$ \\
\hline Fiber $(\%)$ & $0.12 \pm 0.015$ \\
\hline Ascorbic Acid $(\mathrm{mg} / 100 \mathrm{ml})$ & $43.0 \pm 0.04$ \\
\hline
\end{tabular}

Each value is the mean $\pm \operatorname{SD}(n=3)(p<0.05)$.

Storage study of the sweet lemon squash:-

Storage studies were done on both sweet lemon squashes formulated with benzoic acid (T1) and NE of ginger rhizome extract mixed with benzoic acid (T2). Both sweet lemon squashes were kept at room temperature (25 $30^{\circ} \mathrm{C}$ ). Both squashes were found to be stable for a period (60 days) (Figure 5). Changes of TSS [Figure 5(d)], acid content [Figure (5c)] and color[Figure (5f)], ascorbic acid content [Figure (5b)] are similar with both formulations T1 and T2 during storage period. A significant difference of chemical properties of both squash (formulated with benzoic acid T1 and NE T2) were not found and changes of chemical properties were found a parallel of both formulations (T1 and T2). This implies that the NE is effective as a preservative. Due to the antimicrobial properties of NE of the ginger rhizome the spoilage of squash was not observed after sixty days of storage at room temperature. 

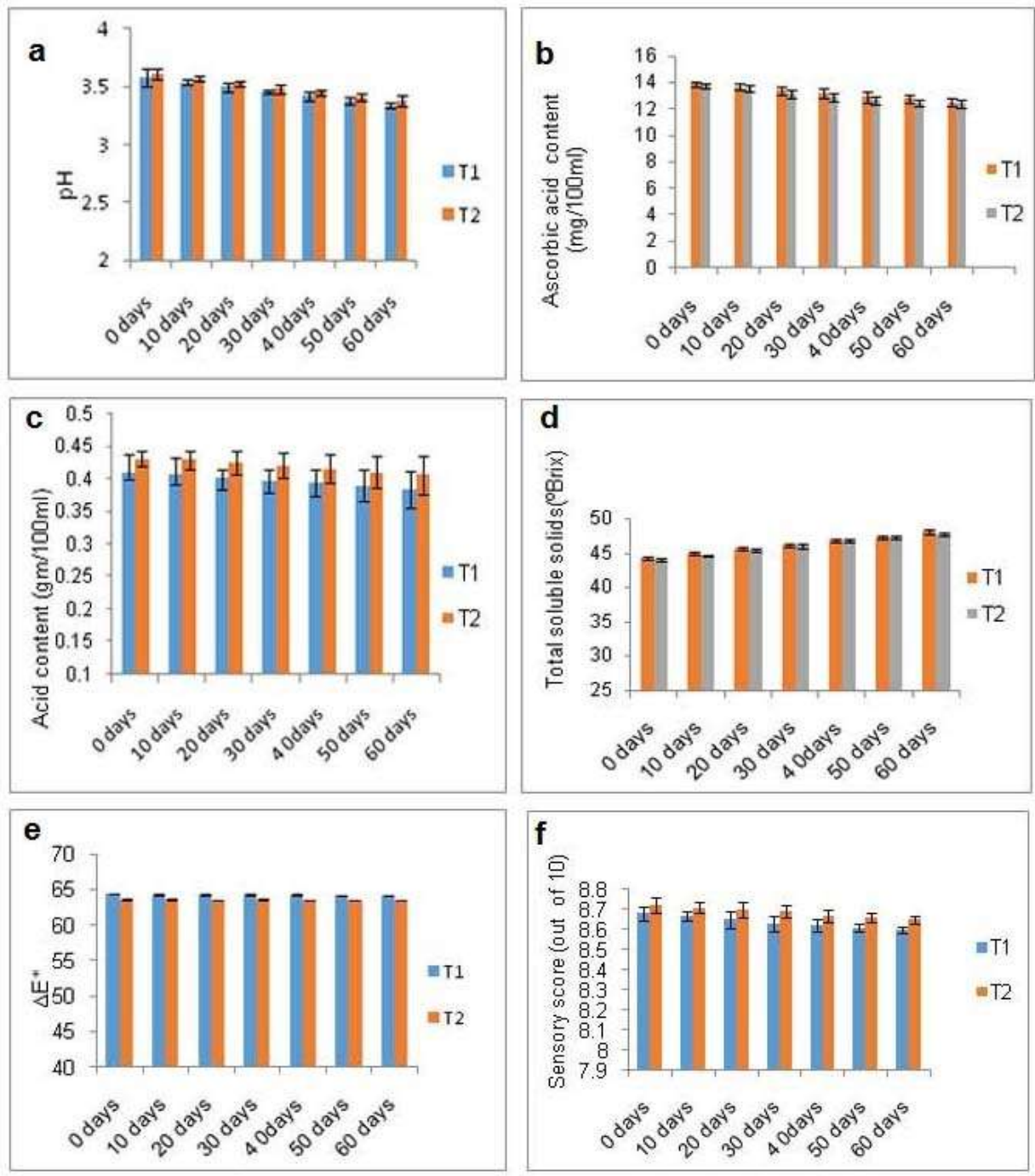

Fig. 5:-Comparison study on a) changes of $\mathrm{pH}, \mathrm{b}$ ) ascorbic acid, c) acid content, d) total soluble solid, e) color and f) Sensory quality of $\mathrm{T} 1$ and $\mathrm{T} 2$

\section{Overall acceptability:-}

The sensory scores obtained for overall acceptability of squash are presented in [Figure $(5 \mathrm{~g})$ ]. The score for the overall acceptability of both formulated sweet lemon squash T1 and T2 was slightly decreased from 8.68 to 8.60 and 8.72 to 8.65 during storage period and significant differences of overall acceptability for both (T1, T2) squashes during the storage period were not found. The squash preserved with NE in combination with benzoic acid and stored in glass bottles retained maximum overall acceptability and negative microbial count. Statistical analysis showed that storage intervals and the treatments had a significant effect on the total bacterial count, color, and overall acceptability of the squash during storage under the ambient conditions. It is evident from the data presented in (Figure 5) that the results of the overall acceptability of sweet lemon squash of both formulation squash of sweet lemon (T1 and T2) were found almost similar. From the overall acceptability score for T2 is 8.65 whereas T1 is 8.60 indicating that the treatment T2 is ideal for the preparation of sweet lemon squash (Figure 5).

\section{Conclusion:-}

The objective of this research was to minimize the use of chemical preservative and find a natural alternative because chemical substances can cause adverse effect on consumer health (Sharma, 2014). On the other hand natural preservatives offer greater advantages over their artificial counterparts due to their non-toxic nature along with a 
wide range of health benefits (Anand and Sati, 2013). According to FPO (Fruit Product Order) maximum limit of benzoic acid in fruit squash is 600mg/L (The Prevention of Food Adulteration Act, 1954 [Act No. 37 of 1954]). In our study, we used only $200 \mathrm{mg} / \mathrm{L}$ of benzoic acid with nanoemulsion of natural compound from ginger, which reduced $66.66 \%$ use of benzoic acid in squash effectively. The nanoemulsion used in squash is active as a natural preservative which can be an effective alternative to the common chemical preservative used in sweet lemon squash. The nanoemulsion used in sweet lemon squash ensures the physical and chemical stability of the squash. Further, the nanoemulsion showed significant antimicrobial activity. Hence the work significantly augments our repertoire of healthier preservatives for food processing.

\section{Reference:-}

1. Amborabé, B.E., Fleurat-Lessard, P., Chollet, J.F., Roblin, G. 2002. Antifungal effects of salicylic acid and other benzoic acid derivatives towards Eutypa lata: Structure-activity relationship. Plant Physiol Biochem 40(12):1051-1060

2. Amrutha, B., Sundar, K., Shetty, P.H. 2017. Spice oil nanoemulsions: Potential natural inhibitors against pathogenic E. coli and Salmonella spp. from fresh fruits and vegetables. LWT - Food Sci Technol 79:152-159

3. Anand, S.P., Sati, N. 2013. Artificial Preservatives and Their Harmful Effects: Looking Toward Nature for Safer Alternatives. Int J Pharm Sci Res IJPSR 4(7):2496-2501

4. A.O.A.C. 2012. Official Methods of Analysis of AOAC International.

5. Bhargava, S., Dhabhai, K., Batra, A.,Sharma, A., Malhotra, B. J.2012. Zingiber officinale: Chemical and phytochemical screening and evaluation of its antimicrobial activities. Chem Pharm Res 04(1):360-364

6. Billmeyer, F.W.1983.Color Science: Concepts and Methods, Quantitative Data and Formulae, 2nd ed., by Gunter Wyszecki and W. S. Stiles, John Wiley and Sons, New York, 1982, 950 pp. Color Res Appl 8(4):262263

7. Brul, S. and Coote, P. 1999. Preservative agents in foods: Mode of action and microbial resistance mechanisms. Int J Food Microbiol 50(1-2):1-17

8. Chirife, J. and Favetto, G.J. 1992. Some physico-chemical basis of food preservation by combined methods. Food Res Int 25(5):389-396

9. CLSI- Performance Standards for Antimicrobial Susceptibility Testing; Twenty-Second Informational Supplement. Vol 32.; 20136

10. Ghosh, V., Mukherjee, A., Chandrasekaran, N. 2013. Ultrasonic emulsification of food-grade nanoemulsion formulation and evaluation of its bactericidal activity. Ultrason Sonochem 20(1):338-344

11. Giriraju, A. and Yunus, G. 2013. Assessment of antimicrobial potential of $10 \%$ ginger extract against Streptococcus mutans, Candida albicans, and Enterococcus faecalis: An in vitro study. Indian J Dent Res 24(4):397

12. Gull, I., Saeed, M., Shaukat, H., Aslam, S.M., Samra, Z.Q., Athar, A.M.2012 Inhibitory effect of Allium sativum and Zingiber officinale extracts on clinically important drug resistant pathogenic bacteria. Annals of Clinical Microbiology and Antimicrobials 11:8

13. Harrigan, W.F. and McCance, M.E.1966. Laboratory Methods in Microbiology. Lab Methods Microbiol 75-76

14. Hasan, H.A., Rasheed Raauf, A.M., Abd Razik, B.M., Rasool Hassan, B.A., 2012. Chemical composition and antimicrobial activity of the crude extracts isolated from Zingiber officinale by different solvents. Pharmaceut Anal Acta 3(9): 184

15. Islam, K., Rowsni, A.A., Khan, M., Kabir, S. 2014. Antimicrobal Activity of Ginger (Zingiber Officinale) Extracts Against Food-Borne Pathogenic Bacteria. Int J Sci Environ Technol 3(3):867-871

16. Jayashree, E., Visvanathan, R., Zachariah, J., 2014. Quality of dry ginger (Zingiber officinale) by different drying methods. J Food sci and technol 51(11): 3190-3198

17. Mishra, P., Rai, G.K., Mahanta, C.L.2015. Process Standardization for Development of Spray-Dried Lemon Juice Powder and Optimization of Amla-Lemon Based RTS (Ready-to-Serve) Drink Using Response Surface Methodology. J Food Process Preserv 39(6):1216-1228

18. Mistewicz, K., Nowak, M.2017. 7 - Prevention of Food Spoilage Using Nanoscale Sensors. doi:10.1016/B9780-12-804301-1.00007-2

19. Nowak, A., Czyzowska, A., Efenberger, M., Krala, L. 2016. Polyphenolic extracts of cherry (Prunus cerasus L.) and blackcurrant (Ribes nigrum L.) leaves as natural preservatives in meat products. Food Microbiol 59:142149

20. Qian, C. McClements, D.J. 2011. Formation of nanoemulsions stabilized by model food-grade emulsifiers using high-pressure homogenization: Factors affecting particle size. Food Hydrocoll 25(5):1000-1008 
21. Rahman, M.S.A., Thangaraj, S. Salique, S.M. Feroz khan, K. Natheer, S.E. 2010. 'Antimicrobial and Biochemical Analysis of Some Spice Extract against Food Spoilage Pathogens', Internet Journal of Food Safety 12: 71-75

22. Rahmani, A.H., Shabrmi, F.M., Aly, S.M. 2014. Active ingredients of ginger as potential candidates in the prevention and treatment of diseases via modulation of biological activities. Int $\mathrm{J}$ Physiol Pathophysiol Pharmacol 6(2):125-136

23. Rawson, A., Patra, A., Tiwari, B.K., Noci, F., Koutchma,T., Brunton, N. 2011 Effect of thermal and non thermal processing technologies on the bioactive content of exotic fruits and their products: Review of recent advances. Food Res Int 44(7): 1875-1887

24. Sagheer, S., Yadav, S.S., Deshmukh, S.G. 2009. Developing a conceptual framework for assessing competitiveness of India's agrifood chain. Int J Emerg Markets 4(2):137-159

25. Santos, M.D., Queirós, R.P., Fidalgo, L.G., Inacio, R.S., Lopes, R.P., Mota, M.J., Sousa, S.G., Delgadillo, I., Saraiva, J.A. 2015Preservation of a highly perishable food, watermelon squash, at and above room temperature under mild pressure (hyperbaric storage) as an alternative to refrigeration. LWT - Food Sci and Technol 62(1): 901-905

26. Sarker, S.D., Nahar, L., Kumarasamy, Y .2007. Microtitre plate-based antibacterial assay incorporating resazurin as an indicator of cell growth, and its application in the in vitro antibacterial screening of phytochemicals. Methods 42(4): 321-324

27. Sharma, S. 2014. Food Preservatives and their harmful effects. Int J Sci Res Publ 5(1):2250-3153

28. Syed, H.M., Ghatge, P.U., Machewad, G., Pawar, S. 2012. Studies on Preparation of Squash from Sweet Orange. 1:311. doi:10.4172/scientificreports.311 1

29. Teixeira, P.C., Leite, G.M., Domingues, R.J., Silva, J., Gibbs, P.A., Ferreira, J.P. 2007. Antimicrobial effects of a microemulsion and a nanoemulsion on enteric and other pathogens and biofilms. Int $\mathrm{J}$ Food Microbiol 118(1):15-19

30. Tyagi, A.K., Gottardi, D., Malik, A., Guerzoni, M.E.2014. Chemical composition, invitro anti-yeast activity and fruit juice preservation potential of lemon grass oil. LWT - Food Sci Technol 57(2):731-737 